\title{
Geochemistry of the Annidale Group: implications for the tectonic setting of Lower Ordovician volcanism in southwestern New Brunswick
}

\author{
M.J. McLeod 1 , J.A. Winchester 2 and A.A. Ruitenberg1 \\ 1 Geological Surveys Branch, Department of Natural Resources and Energy, \\ P.O. Box 1519, Sussex, New Brunswick E0E 1P0, Canada \\ 2Department of Geology, University of Keele, Keele, Staffordshire, England ST5 5BG \\ Date Received February 12, 1993 \\ Date Accepted May 3, 1994
}

\begin{abstract}
Chemical analyses from volcanic rocks in the Lower Ordovician Annidale Group in southern New Brunswick indicate that it contains two main suites. The volumetrically more abundant suite is bimodal, and consists of within-plate tholeiitic basalt and rhyolite. The other suite contains rocks that exhibit features indicative of oceanic or possibly subduction-related magmatism. The chemistry of the former suite is consistent with the current interpretation that Ordovician volcanism in southwestern New Brunswick occurred in a back-arc basin. The latter suite, situated near the highly-sheared southeastern margin of the Annidale Group, apparently contains remnants of a different magmatic series near the suture zone between the Gander Zone and the surface expression of the Avalon Zone to the southeast.
\end{abstract}

Les analyses chimiques des roches volcaniques du Groupe d'Annidale, de l'Ordovicien inférieur, dans le sud du NouveauBrunswick indique que celui-ci comprend deux suites principales. La suite la plus abondante en termes de volume est bimodale et comprend des basaltes tholéiitiques intraplaques et des rhyolites. L'autre suite contient des roches qui montrent des caractéristiques indiquant un magmatisme océanique ou possiblement relié à la subduction. La chimie de la première suite est en accord avec l'interprétation prévalant actuellement voulant que le volcanisme ordovicien du sud du NouveauBrunswick ait eu lieu dans un bassin d'arrière-arc. La seconde suite, située près de la bordure sud-est, fortement cisaillée, du Groupe d'Annidale, contient apparemment des reliques d'une série magmatique différente près de la zone de suture entre la zone de Gander et l'expression en surface de la zone d'Avalon vers le sud-est.

[Traduit par la rédaction]

\section{INTRODUCTION}

New Brunswick is underlain by three (Avalon, Gander and Dunnage; Fig. 1) of the five Appalachian tectonostratigraphic zones defined by Williams (1979). The Gander Zone is generally considered to represent a Cambro-Ordovician sedimentary apron deposited off the western margin of the Avalonian microcontinent as the Iapetus Ocean opened to the west. The Dunnage Zone consists of marine, Early to Middle Ordovician volcano-sedimentary sequences that developed within the Iapetus system. The Gander and Dunnage zones in New Brunswick were modified and divided into subzones by van Staal and Fyffe (1991), who assigned the Cookson Group (St. Croix Subzone) to the Gander Zone (Fig. 1). McLeod et al. (1992) demonstrated that volcanic units in the recently recognized Annidale Group are contemporaneous with the Cookson Group (Ludman, 1987; Fyffe and Riva, 1990) of the St. Croix Subzone and that tentative correlations can be established between these two groups. Hence, the Annidale Group is also provisionally assigned to the Gander Zone and the area in which it occurs is termed the Annidale Subzone.

Recent studies of Ordovician rocks in New Brunswick (e.g., Fyffe et al., 1988, 1990; Dostal, 1989; van Staal and Fyffe, 1991; van Staal et al., 1991) underscore the significance of geochemical characteristics in interpreting the tectonic history of the Dunnage and Gander zones. Based partially on chemistry, recent models for the Lower to Middle Ordovician in New Brunswick (e.g., van Staal et al., 1991) invoke development of a Lower to Middle Ordovician arc (the Woodstock-Meductic arc, Dostal, 1989) above a southeastward-dipping subduction zone. According to this model, the arc subsequently rifted and most of it migrated northwestward to form the Popelogan Arc, leaving remnants (westernmost part of the Hayesville Subzone, Fig. 1) on the southeastern side of a developing back-arc basin. The extensive, mainly Middle Ordovician, volcanic belts of the northern Miramichi Highlands and the Elmtree inlier thus include rocks with field relationships and chemical signatures suggesting both rifted continental margin and oceanic back-arc environments (the Tetagouche and Fournier groups, respectively, of the Bathurst Subzone) erupted during the formation of a midOrdovician back-arc basin (van Staal et al., 1991).

Geological mapping and preliminary chemical studies of the Annidale Group (McLeod et al., 1991a, 1992; van Staal and Fyffe, 1991) indicated the presence of possible arc-related (back-arc and ophiolitic) volcanic rocks. The volcanic rocks could be associated with the "Woodstock-Meductic arc" (van Staal and Fyffe, 1991), or more likely could include vestiges of a separate arc associated with the St. Croix Subzone (McLeod et al., 1991b). This paper presents additional chemical data from the Annidale Group, compares it with the chemistry of other Ordovician volcanic groups in southern New Brunswick and Maine, and proposes a model for the tectonic setting during their formation. 


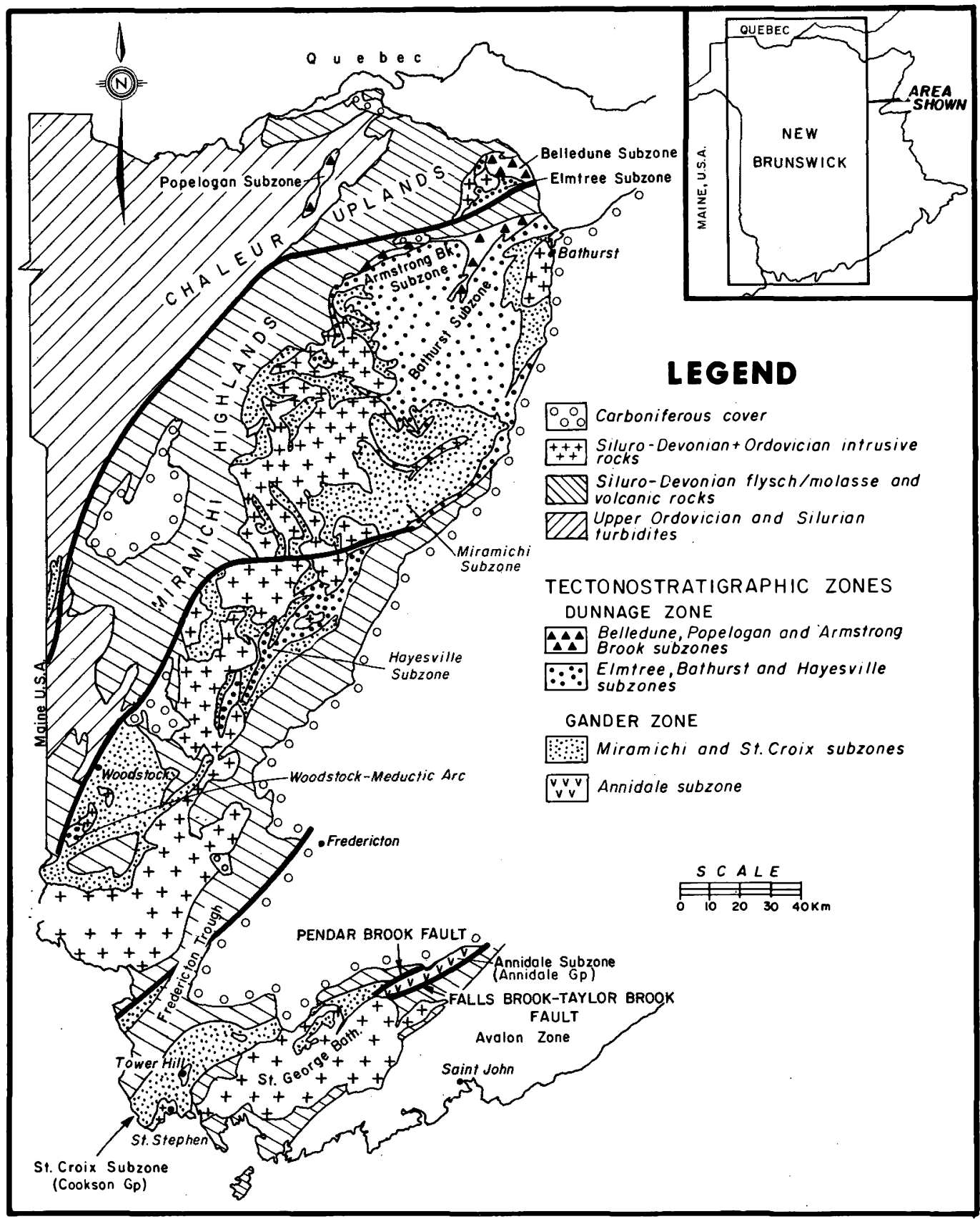

Fig. 1. Generalized geology of New Brunswick illustrating major tectonostratigraphic subdivisions (modified after van Staal and Fyffe, 1991).

\section{Geology of the Annidale Group}

The Lower Ordovician Annidale Group, from which U-Pb dates of $493 \pm 2 \mathrm{Ma}$ and $497 \pm 10 \mathrm{Ma}$ were obtained (McLeod et al., 1992), consists of a variety of marine volcanic and sedimentary rocks. It occupies a position analogous to the Cookson Group, situated north of the northernmost exposures of the Avalon Zone and south of the Siluro-Devonian cover sequence of the Fredericton Trough (Fig. 1). In the Annidale area, the sedimentary and minor volcanic rocks of the Queen Brook Formation (McCutcheon and Ruitenberg, 1987), of unknown affinity, separates the Annidale Group from the Avalon Zone to the south. The southeastern and northwestern boundaries of the Annidale Group are marked by the Falls Brook - Taylor Brook Fault and the Pendar Brook Fault, respectively. The northeast- ern extension is buried beneath Carboniferous cover rocks and the group is terminated to the southwest by the Siluro-Devonian Saint George Batholith (Fig. 1).

The Annidale Group comprises three main units (Fig. 2), each of which contains distinctive lithologies and/or structures. The two southern units, the East Scotch Settlement and Lawson Brook formations, contain all of the volcanic rocks in the group. The northern unit, the Canaan Forks sequence, is devoid of volcanic rocks and is not considered further here. It is emphasized that determination of stratigraphic relationships between and within these units is hampered by paucity of outcrops, by numerous northeast- and northwest-trending faults, shear zones and alteration zones that typify the group in general, and by Carboniferous cover. 


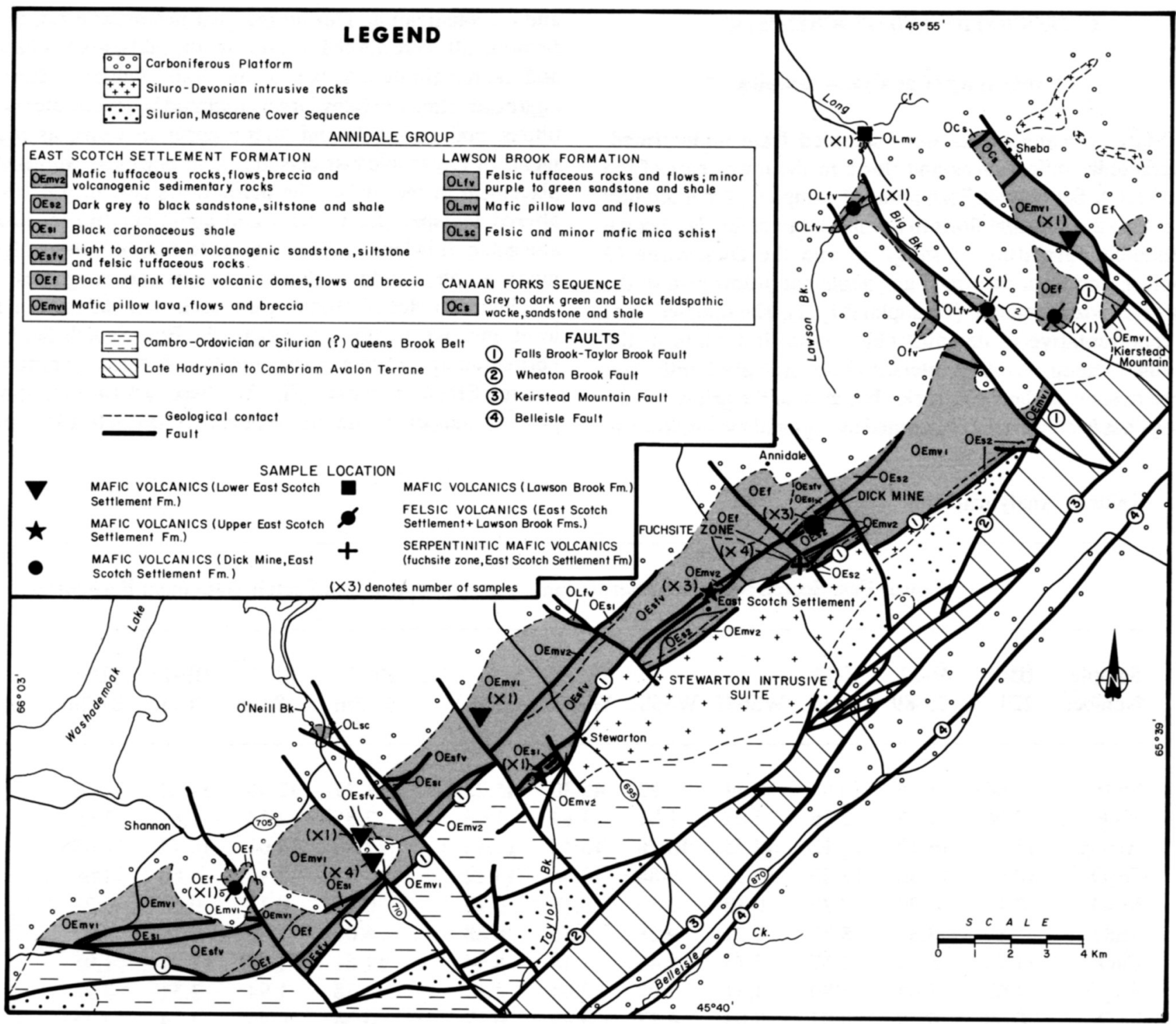

Fig. 2. Geological map of the Annidale Subzone showing geochemical sample localities.

The East Scotch Settlement Formation is a steeply dipping sequence that apparently youngs toward the south. Although cut by several faults that parallel the strike of the formation, a crude stratigraphy has been established (McLeod et al., 1992). It contains deformed and undeformed pillow lavas, mafic tuffs and mafic volcanic breccias at the base, overlain by light to dark green volcaniclastic sandstone and siltstone interbedded with fine-grained felsic tuffaceous rocks. Felsic domes, breccias and flows are spatially associated with these rocks. The youngest rocks are alternating dark green and grey sandstone, siltstone and shale units intercalated with mafic flows, mafic tuffs and volcanogenic sedimentary rocks. The Dick Mine (Fig. 2) lies within these units. Black carbonaceous shale units up to several tens of metres thick occur sporadically throughout the formation.

The East Scotch Settlement Formation, especially the upper part, is characterized by zones of intense alteration that are generally associated with faults. Examples include volcanic rocks in the Dick Mine area and rocks in the fuchsite zone (Fig.
2). The fuchsite zone is an altered tectonic breccia at least 100 $\mathbf{m}$ wide, characterized by intense high-chromian mica, silicic and, locally, serpentinitic alteration. Southeast-dipping thrusts and shear zones are particularly abundant along the southeastern margin of the formation, and northeast-trending vertical shear zones and faults occur throughout. These faults form the contacts between many of the map units.

The Lawson Brook Formation, which occurs in scattered inliers in Carboniferous cover rocks along the northwestern margin of the East Scotch Settlement Formation, consists of deformed interbedded felsic tuffs and massive flows which dip shallowly to moderately to the northwest. Locally, minor amounts of sheared green to purple siltstone and shale, intensely altered granitoid rocks, deformed pillow lavas, and felsic mica schist occur in the formation. Shear zones and, locally, thrusts are oriented subparallel or at shallow angles to the bedding. Inheritance in zircon from the Lawson Brook Formation indicates that the age of the basement is about $1000 \mathrm{Ma}$ (McLeod et al., 1992). 


\section{Petrography AND geochemistry}

\section{Petrography of analyzed samples}

Mafic volcanic rocks were sampled from undeformed, amygdaloidal pillow lavas and flows in the lower part of the East Scotch Settlement Formation (7 samples), from slightly deformed amygdaloidal flows in the upper part of the East Scotch Settlement Formation (4 samples) and the Dick Mine (3 samples), and from deformed amygdaloidal pillow lava in the Lawson Brook Formation (1 sample) (Fig. 2). The sampled units are representative of demonstrable mafic flow units in the Annidale Group. Primary interstitial textures are faintly preserved in some of the mafic rocks, but most of the primary mineralogy has been variably obliterated by regional metamorphism and carbonatization. During regional metamorphism, the mafic minerals were altered to chlorite, the feldspars to muscovite and the remaining matrix to a fine-grained chlorite-muscovite aggregate. Ilmenite (now largely replaced by leucoxene) is ubiquitous, and carbonate and quartz occur in veins, as replacements of larger feldspar crystals, or in places as wholesale replacement of the rocks. The mafic flows contain rare $(<5 \%)$ altered feldspar phenocrysts and abundant (up to 20-25\%) amygdales filled with calcite or chlorite. Sulphide minerals commonly accompany the carbonate in veins and amygdales.

Four samples of felsic volcanic rocks were taken from highlevel, massive rhyolitic domes in the East Scotch Settlement Formation and from a massive to flow-banded rhyolite in the Lawson Brook Formation (Fig. 2). These rocks are variably porphyritic and contain unaltered phenocrysts (up to $15 \%$ ), mostly

Table 1. Analytical data.

Lower East Scotch Settlement Formation

\begin{tabular}{|c|c|c|c|c|c|c|c|c|c|c|c|}
\hline $\begin{array}{l}\text { Sample } \\
\text { Number }\end{array}$ & $\begin{array}{l}\text { HB74 } \\
224\end{array}$ & $\begin{array}{l}\mathrm{H}-12 \\
25-89\end{array}$ & $\begin{array}{l}\mathrm{H}-13 \\
36-90\end{array}$ & WS681 & WS682 & WS683 & WS684 & $\begin{array}{l}\text { BF-1 } \\
67.5 \mathrm{~m}\end{array}$ & $\begin{array}{l}\text { BF-1 } \\
68.0 \mathrm{~m}\end{array}$ & $\begin{array}{l}\text { BF-1 } \\
71.0 \mathrm{~m}\end{array}$ & $\begin{array}{l}\text { TB-1 } \\
81.2 \mathrm{~m}\end{array}$ \\
\hline $\mathrm{SiO}_{2}$ & 43.66 & 44.25 & 46.95 & 50.34 & 45.22 & 45.30 & 45.28 & 31.29 & 42.56 & 34.72 & 52.68 \\
\hline $\mathrm{TiO}_{2}$ & 2.06 & 1.55 & 2.36 & 2.07 & 1.81 & 1.84 & 1.66 & 2.85 & 2.14 & 1.81 & 3.60 \\
\hline $\mathrm{Al}_{2} \mathrm{O}_{3}$ & 15.29 & 16.17 & 15.12 & 17.35 & 16.76 & 16.45 & 15.53 & 13.56 & 16.01 & 16.72 & 14.65 \\
\hline $\mathrm{Fe}_{2} \mathrm{O}_{3} \mathrm{~T}$ & 10.02 & 13.36 & 12.22 & 10.30 & 9.88 & 10.64 & 13.12 & 9.93 & 12.15 & 5.00 & 14.69 \\
\hline $\mathrm{MnO}$ & 0.16 & 0.20 & 0.25 & 0.12 & 0.15 & 0.16 & 0.18 & 0.17 & 0.13 & 0.13 & 0.27 \\
\hline $\mathrm{MgO}$ & 5.13 & 8.83 & 8.32 & 6.21 & 9.28 & 7.75 & 8.88 & 4.09 & 7.65 & 2.70 & 3.87 \\
\hline $\mathrm{CaO}$ & 11.76 & 8.71 & 7.57 & 5.15 & 9.43 & 11.18 & 8.94 & 17.61 & 6.68 & 17.27 & 1.95 \\
\hline $\mathrm{Na}_{2} \mathrm{O}_{3}$ & 4.62 & 3.64 & 3.80 & 4.31 & 2.98 & 2.04 & 2.71 & 3.78 & 1.94 & 2.31 & 3.22 \\
\hline $\mathrm{K}_{2} \mathrm{O}$ & 0.38 & 0.08 & 0.07 & 0.04 & 0.27 & 0.09 & 0.29 & 0.88 & 0.93 & 3.74 & 0.35 \\
\hline $\mathrm{P}_{2} \mathrm{O}_{5}$ & 0.23 & 0.18 & 0.30 & 0.24 & 0.19 & 0.17 & 0.18 & 0.42 & 0.28 & 0.23 & 0.35 \\
\hline L.O.I. & 7.07 & 3.69 & 3.45 & 4.24 & 4.47 & 5.22 & 3.38 & 15.56 & 9.52 & 13.60 & 4.07 \\
\hline Total & 100.38 & 100.66 & 100.41 & 100.37 & 100.44 & 100.84 & 100.15 & 100.14 & 99.99 & 98.23 & 99.70 \\
\hline $\mathrm{Ba}$ & 339 & 53 & 72 & 42 & 423 & 163 & 131 & 260 & 323 & 958 & 174 \\
\hline $\mathrm{Cl}$ & 116 & 105 & 145 & 93 & 93 & 105 & 95 & 108 & 195 & 271 & 99 \\
\hline $\mathrm{Cr}$ & 372 & 218 & 229 & 274 & 147 & 153 & 311 & 38 & 22 & 151 & bdl \\
\hline $\mathrm{Cu}$ & 50 & 38 & 49 & 31 & 58 & 63 & 45 & 72 & 79 & 62 & 124 \\
\hline $\mathrm{Ga}$ & 13 & 14 & 18 & 15 & 14 & 17 & 16 & 20 & 20 & 19 & 21 \\
\hline $\mathrm{Nb}$ & 9 & 5 & 10 & 8 & 6 & 6 & 6 & 13 & 10 & 7 & 5 \\
\hline $\mathrm{Ni}$ & 166 & 124 & 127 & 132 & 104 & 97 & 128 & 39 & 51 & 81 & 17 \\
\hline $\mathrm{Pb}$ & bdl & 2 & 1 & bdl & 3 & 4 & 3 & 5 & 2 & bdl & 7 \\
\hline $\mathrm{Rb}$ & 7 & bdl & 1 & 2 & 4 & 3 & 5 & 23 & 24 & 94 & 13 \\
\hline $\mathrm{Sr}$ & 260 & 239 & 220 & 274 & 210 & 213 & 325 & 404 & 147 & 250 & 65 \\
\hline V & 338 & 355 & 370 & 301 & 245 & 260 & 352 & 422 & 338 & 258 & 442 \\
\hline Y & 40 & 29 & 39 & 27 & 28 & 28 & 31 & 37 & 26 & 25 & 43 \\
\hline Zn & 86 & 117 & 102 & 69 & 65 & 69 & 105 & 139 & 82 & 100 & 156 \\
\hline $\mathrm{Zr}$ & 164 & 88 & 172 & 189 & 152 & 155 & 99 & 265 & 198 & 156 & 105 \\
\hline
\end{tabular}


composed of potassium feldspar, less commonly quartz, and rarely plagioclase. The matrix, which is composed of a finegrained mosaic of quartz, feldspar and scattered Fe-Ti oxides, contains minor amounts of secondary muscovite and chlorite.

Four samples collected south of Annidale at the fuchsite zone are all extensively altered and variably deformed. They retain little of their original mineralogy and now consist of sheared domains of serpentinite and/or chlorite, separated from one another by broad anastomosing shear zones filled with recrystallized granular quartz which thus provides evidence of later silicification. Locally, fine-grained segregations of magnetite or chrome-spinel occur in aggregates with quartz. No original textures were seen in thin section. The overall appearance of these rocks compared to the identifiable metasedimentary rocks in the fuchsite zone, however, indicates an igneous protolith.

\section{Analytical procedures and effects of alteration}

Analytical results are shown on Tables 1 and 2. Analyses for major elements and most trace elements were done at Keele University using XRF spectrometry. Representative samples were also analysed by INAA for $\mathrm{Cs}, \mathrm{Hf}, \mathrm{Sc}$, Ta and Th and by ICP for rare earth elements (REE). Analytical methods are described in Winchester et al. (1992). At some localities more than one sample was collected to determine intra-unit variation.

Table 1 Continued.

Lawson

Brook

Dick Mine $\quad$ Formation Felsic Volcanics Annidale Group $\quad$ Fuchsitic Zone

$\begin{array}{lllllllllll}\text { Sample } & & & & \text { H-13 } & \text { H-12 } & \text { H-13 } & \text { H-13 } & \text { H-13 } & \text { BH83901 } & \text { BH83901 } \\ \text { Number } & \text { WS676 WS677 WS678 } & 21-90 & 13-89 & 25-90 & 26-90 & 9-90 & 225 \mathrm{~m} & 229 \mathrm{~m} & \text { WS679 } & \text { WS680 }\end{array}$

\begin{tabular}{lrrrrrrrrrrrr}
\hline & & & & & & & & & & & & \\
$\mathrm{SiO}_{2}$ & 53.85 & 41.16 & 48.20 & 53.20 & 80.55 & 78.44 & 77.11 & 84.35 & 70.96 & 68.80 & 65.48 & 59.03 \\
$\mathrm{TiO}_{2}$ & 1.43 & 0.67 & 0.71 & 3.53 & 0.12 & 0.13 & 0.17 & 0.10 & 0.48 & 0.61 & 0.45 & 0.55 \\
$\mathrm{Al}_{2} \mathrm{O}_{3}$ & 16.14 & 15.79 & 14.80 & 16.15 & 9.75 & 11.22 & 11.88 & 8.38 & 11.67 & 11.07 & 9.37 & 10.94 \\
$\mathrm{Fe}_{2} \mathrm{O}_{3} \mathrm{~T}$ & 10.70 & 10.54 & 11.06 & 10.46 & 0.24 & 1.17 & 1.29 & 0.31 & 6.41 & 8.54 & 8.13 & 9.09 \\
$\mathrm{MnO}$ & 0.13 & 0.18 & 0.19 & 0.33 & 0.01 & 0.02 & 0.01 & 0.01 & 0.20 & 0.23 & 0.26 & 0.28 \\
$\mathrm{MgO}$ & 8.61 & 9.83 & 8.01 & 1.78 & 0.01 & 0.22 & 0.28 & 0.02 & 1.90 & 2.45 & 11.25 & 13.73 \\
$\mathrm{CaO}$ & 0.61 & 8.65 & 10.20 & 3.64 & 0.03 & 0.00 & 0.00 & 0.00 & 0.61 & 0.41 & 0.10 & 0.03 \\
$\mathrm{Na}_{2} \mathrm{O}_{3}$ & 3.73 & 1.67 & 2.91 & 4.30 & 0.48 & 1.64 & 0.56 & 1.93 & 0.03 & 0.02 & 0.00 & 0.00 \\
$\mathrm{~K}_{2} \mathrm{O}$ & 0.03 & 0.49 & 0.02 & 1.65 & 7.66 & 6.34 & 7.33 & 3.92 & 3.25 & 2.72 & 0.02 & 0.01 \\
$\mathrm{PO}_{2}$ & 0.14 & 0.06 & 0.07 & 0.84 & 0.03 & 0.04 & 0.03 & 0.04 & 0.04 & 0.05 & 0.05 & 0.06 \\
$\mathrm{L.O} . \mathrm{I}$. & 4.61 & 10.85 & 3.54 & 4.20 & 0.37 & 0.52 & 0.84 & 0.29 & 4.07 & 5.14 & 5.04 & 5.99 \\
$\mathrm{Total}$ & 99.98 & 99.89 & 99.91 & 100.08 & 99.25 & 99.74 & 99.50 & 99.35 & 99.62 & 100.04 & 100.15 & 99.71 \\
& & & & & & & & & & & & \\
$\mathrm{Ba}$ & 73 & 93 & 10 & 460 & 386 & 346 & 211 & 253 & 717 & 449 & 53 & 523 \\
$\mathrm{Cl}$ & 103 & 104 & 106 & 117 & 95 & 149 & 99 & 101 & 85 & 86 & 66 & 85 \\
$\mathrm{Cr}$ & 5 & 456 & 407 & bdl & 28 & 20 & 22 & 29 & 1631 & 1757 & 1861 & 2239 \\
$\mathrm{Cu}$ & 20 & 15 & 22 & 32 & 15 & 5 & 5 & bdl & 11 & 27 & 22 & 13 \\
$\mathrm{Ga}$ & 14 & 10 & 10 & 19 & 7 & 18 & 22 & 7 & 9 & 13 & 6 & 12 \\
$\mathrm{Nb}$ & 9 & 3 & 3 & 26 & 12 & 49 & 40 & 48 & 2 & 3 & 1 & 2 \\
$\mathrm{Ni}$ & 54 & 142 & 104 & 8 & 2 & 2 & 6 & 4 & 334 & 483 & 674 & 1015 \\
$\mathrm{~Pb}$ & bdl & bdl & 2 & 4 & 10 & bdl & bdl & bdl & 6 & 29 & 17 & 14 \\
$\mathrm{Rb}$ & 4 & 22 & 2 & 25 & 63 & 142 & 177 & 76 & 121 & 104 & 4 & 4 \\
$\mathrm{Sr}$ & 19 & 95 & 133 & 126 & 24 & 29 & 23 & 44 & 16 & 12 & 4 & 8 \\
$\mathrm{~V}$ & 429 & 248 & 250 & 415 & 8 & 10 & bdl & 10 & 210 & 307 & 215 & 260 \\
$\mathrm{Y}$ & 35 & 21 & 26 & 53 & 53 & 108 & 93 & 152 & 13 & 17 & 8 & 6 \\
$\mathrm{Zn}$ & 113 & 83 & 71 & 137 & 47 & 35 & 76 & 21 & 98 & 78 & 311 & 334 \\
$\mathrm{Zr}$ & 157 & 32 & 34 & 444 & 192 & 581 & 427 & 261 & 26 & 37 & 27 & 29 \\
& & & & & & & & & & & & \\
\hline
\end{tabular}

bdl $=$ below detection limit 
Table 2. Trace element and REE data for selected samples.

Sample

Number WS681 WS682 WS678

\begin{tabular}{cccc}
\hline & & & \\
$\mathrm{Cs}$ & 0.27 & 0.44 & 0.18 \\
$\mathrm{Hf}$ & 4.20 & 3.30 & 0.89 \\
$\mathrm{Sc}$ & 37 & 39 & 133 \\
$\mathrm{Ta}$ & 0.51 & 0.32 & 0.10 \\
$\mathrm{Th}$ & 0.50 & 0.23 & 0.05 \\
$\mathrm{La}$ & 8.6 & 6.2 & 0.5 \\
$\mathrm{Ce}$ & 23.3 & 17.5 & 1.5 \\
$\mathrm{Pr}$ & 3.35 & 2.75 & 0.36 \\
$\mathrm{Nd}$ & 16.5 & 13.9 & 3.1 \\
$\mathrm{Sm}$ & 4.29 & 3.77 & 1.36 \\
$\mathrm{Eu}$ & 1.27 & 1.23 & 0.66 \\
$\mathrm{Gd}$ & 4.66 & 4.39 & 2.45 \\
$\mathrm{Dy}$ & 5.08 & 4.87 & 3.97 \\
$\mathrm{Ho}$ & 0.91 & 0.87 & 0.80 \\
$\mathrm{Er}$ & 2.53 & 2.49 & 2.61 \\
$\mathrm{Yb}$ & 2.22 & 2.23 & 2.63 \\
$\mathrm{Lu}$ & 0.31 & 0.32 & 0.39 \\
& & & \\
\hline
\end{tabular}

Because of the intensity and pervasiveness of deformation, carbonatization, metamorphism and, locally, silicification which commonly characterises the volcanic rocks of the Annidale Group, most samples were not fresh. Evidence of considerable major element mobility in the mafic rocks is provided by a $\mathrm{Na}_{2} \mathrm{O}-$ $\mathrm{CaO}$ diagram (Fig. 3a), which shows that all but a few samples from the Lower East Scotch Settlement Formation plot outside the rectangle depicting the field of "normal" basalt. Several samples show $\mathrm{CaO}$ depletion and some $\mathrm{Na}_{2} \mathrm{O}$ enrichment characteristic of spilitization. Also, the metasomatised rocks from the fuchsite zone show effects of silica enrichment. Hence the relatively immobile high field strength elements (HFSE) are mainly used here to interpret the nature and tectonic setting of the volcanic rocks. Also shown on the chemical variation diagrams (Figs. 3, 4) for comparison are analyses from Lower Ordovician rocks in other parts of southern New Brunswick and Maine after Dostal (1989) and Fyffe et al. (1988).

\section{Chemical characteristics}

On the $\mathrm{FeO} / \mathrm{MgO}-\mathrm{SiO}_{2}$ discriminant diagram (Fig. $3 \mathrm{~b}$ ), the mafic samples plot in the iron-enriched tholeiitic field. The $\mathrm{Zr} / \mathrm{TiO}_{2}-\mathrm{Nb} / \mathrm{Y}$ diagram shows that the mafic samples are subalkalic basalts, whereas the felsic samples have rhyolitic compositions (Fig. 3c). Volcanism was essentially bimodal. A MgO$\mathrm{FeO}$ (total) diagram (Fig. 3d) indicates that the mafic magmas are high-magnesian basalts with some scattering toward low$\mathrm{Mg}$ basalt and ferrobasalt.

On the $\mathrm{Zr}-\mathrm{TiO}_{2}$ diagram (Fig. $4 \mathrm{a}$ ), most samples plot in the overlapping mid-ocean ridge or within-plate basalt fields. The main exceptions are two samples from sheared flows from the Dick Mine, which plot in the island arc tholeiite field. A $\mathrm{Zr}-\mathrm{Zr} / \mathrm{Y}$ diagram (Fig. 4b) shows the within-plate nature of most samples, with the exception of the same two samples from the Dick Mine. This diagram indicates that contrasting $\mathrm{Zr} / \mathrm{Y}$ values typify mafic rocks from both the lower and upper East Scotch Settlement Formation, suggesting that different magmas are present in each part of the formation. A Ti-V diagram (Fig. 4c) shows that mafic rocks in the Annidale Group have high Ti and $\mathrm{V}$, indicative of a within-plate origin, except the Dick Mine samples which plot in the arc-related field. Classification of the samples from the fuchsite zone is hampered by intense alteration. High concentrations of compatible immobile elements ( $\mathrm{Cr}$ and $\mathrm{Ni}$ ), however, suggest a possible ultramafic protolith.

A chondrite-normalized rare earth element (REE) plot (Fig. 5a) shows that mafic volcanic rocks from the lower part of the East Scotch Settlement Formation display a gently sloping REE profile, with no Eu anomaly, whereas the Dick Mine basalt displays marked LREE depletion. These differences are also shown on a multielement plot (Fig. 5b), on which the profile of the sample from the Dick Mine reveals depletion of most elements relative to mid-ocean ridge basalt. The apparent $\mathrm{Nb}$ peak may be spurious, as the recorded value of $3 \mathrm{ppm}$ is below the limit of detection by XRF and is unlikely to be precise. The felsic rocks broadly support the tectonic setting indicated by the mafic rocks across most of the area. On a Nb-Y discriminant diagram (Fig. 4d), they plot in the within-plate field, suggesting that they were emplaced in an extensional setting.

\section{COMPARISONS AND DISCUSSION}

Coeval mafic volcanic rocks from the St. Stephen and Penobscot (Maine) areas (Fyffe et al., 1988) in the St. Croix Subzone are plotted on Figures 3 and 4 for comparison. The mafic rocks from the St. Croix Subzone have been interpreted to represent volcanism in an extensional environment marginal to an ocean basin, and display alteration and chemical modification similar to those in the Annidale Subzone (Fyffe et al., 1988). They consistently plot as tholeiitic basalts in the withinplate field on most discriminant diagrams, like most mafic samples from the Annidale Group (Figs. 3, 4).

The calc-alkaline volcanic rocks from the WoodstockMeductic area, which were extruded in an arc or backarc environment (Dostal, 1989), are also plotted for comparison on the tectonic setting discrimination diagrams (Fig. 4). The mafic samples plot in the arc field on Figure $4 \mathrm{a}$ and $\mathrm{c}$, as do the lowTi Dick Mine samples. The felsic volcanic rocks plot in the arc field (Fig. 4d), consistent with arc affinities for the suite. This contrasts with felsic rocks from the Annidale Group which plot in the within-plate field.

The main problem in interpreting the chemical data from the Annidale Group is reconciling the mixed chemical signatures of the Dick Mine samples with the rest of the samples. The presence of intensely metasomatized rocks in adjacent major shear zones (e.g., the fuchsite zone) indicates that some of the Dick Mine rocks could have been brought by shearing to their present position and, accordingly, could be genetically unrelated to the rest of the group. Although meagre, available field evidence indicates that this is not the case. Stratigraphy in the 

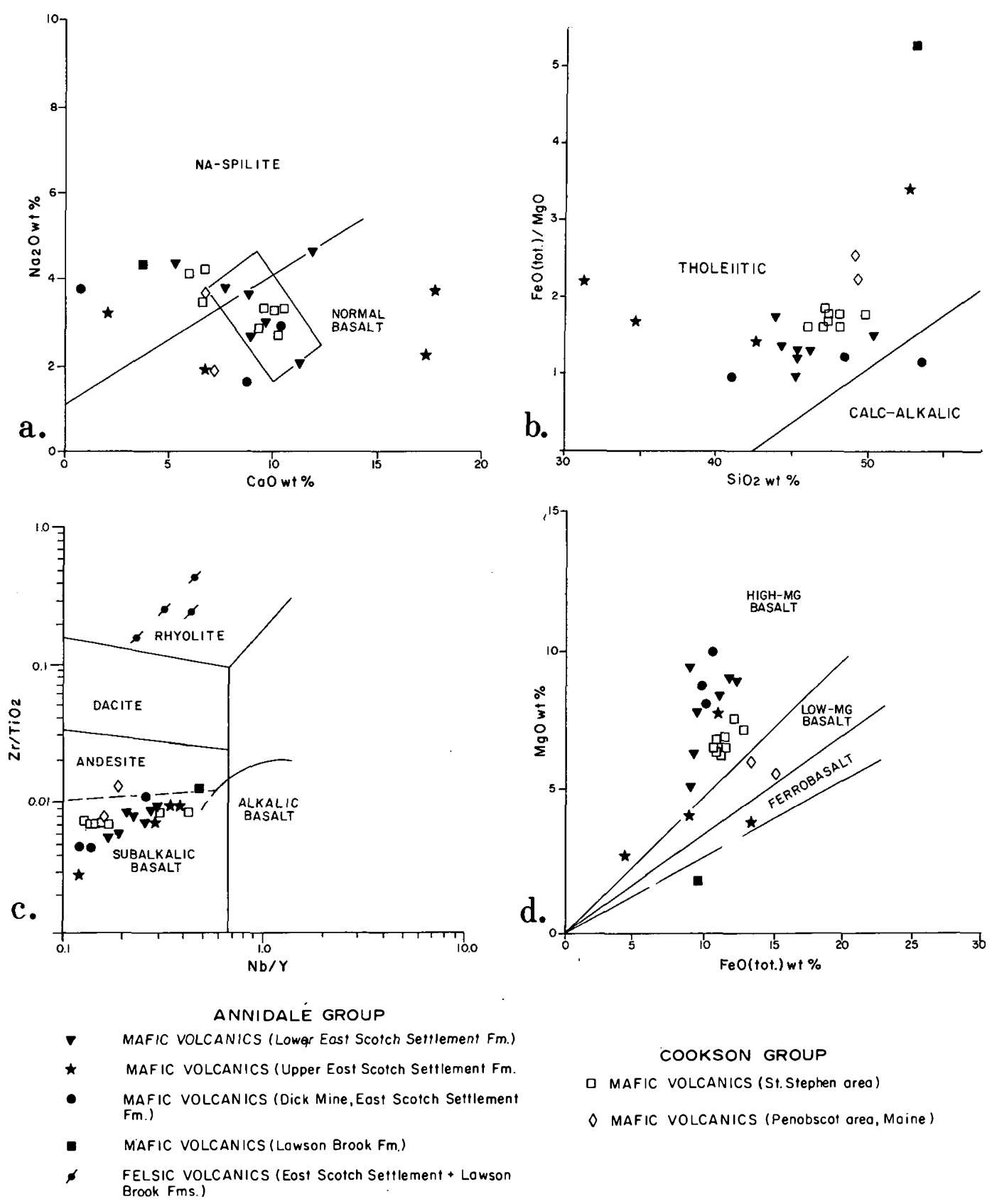

COOKSON GROUP

口 MAFIC VOLCANICS (St. Stephen area)

$\checkmark$ MAFIC VOLCANICS (Penobscot oreo, Moine)

Fig. 3. Diagrams illustrating chemical classification of mafic and felsic volcanic samples from the Annidale Group and of contemporary volcanic suites in the Cookson Group. (a) $\mathrm{Na}_{2} \mathrm{O}-\mathrm{CaO}$ diagram illustrating mobility of these elements relative to unaltered basaltic rocks (fields after Graham, 1976; Stillman and Williams, 1979). (b) $\mathrm{FeO}$ (total)/MgO-SiO 2 diagram (fields after Miyashiro, 1974). (c) $\mathrm{Zr} / \mathrm{TiO} 2-\mathrm{Nb} / \mathrm{Y}$ discriminant diagram (fields after Winchester and Floyd, 1977). (d) $\mathrm{MgO}-\mathrm{FeO}$ (total) diagram showing compositional range of the basalts (fields after Wood, 1978).

Dick Mine area appears too be continuous with the rest of the East Scotch Settlement Formation, and available drill core from the area does not reveal major structural discontinuities. Two additional samples from mafic flows in closely spaced drill holes at the Dick Mine were analyzed for partial chemical data by $\mathrm{XRF}$ spectrometry. These samples also yielded contrasting low and high $\mathrm{HFSE}$ concentrations $\left(\mathrm{TiO}_{2}=1.07 \%\right.$ versus $0.55 \%$; $\mathrm{Zr}=333 \mathrm{ppm}$ versus $39 \mathrm{ppm}$.). Similar extreme variations in chemistry may occur within individual formations in back-arc basins, and discrimination diagrams may also give mixed signatures for tectonic setting (Barker et al., 1989).

Volcanic rocks in the Annidale Group (except possibly those from the Dick Mine and the fuchsite zone) were emplaced in an extensional basin, which may have been a back-arc basin behind a developing arc. This arc could have been the Early Ordovician Woodstock-Meductic arc to the northwest or an as yet unrecognized or buried volcanic belt.

The volcanic rocks of the Dick Mine and possibly ultramafic rocks represented by the fuchsite zone suggest the existence of a suture zone along the southeastern margin of the Annidale Group. Only in these rocks was a LREE-depleted REE profile displayed, together with depletion of HFSE, possibly indicating an arc affinity. If so, the relationship of these rocks to those in coeval arcs in the area remains unknown. The tectonic situa- 

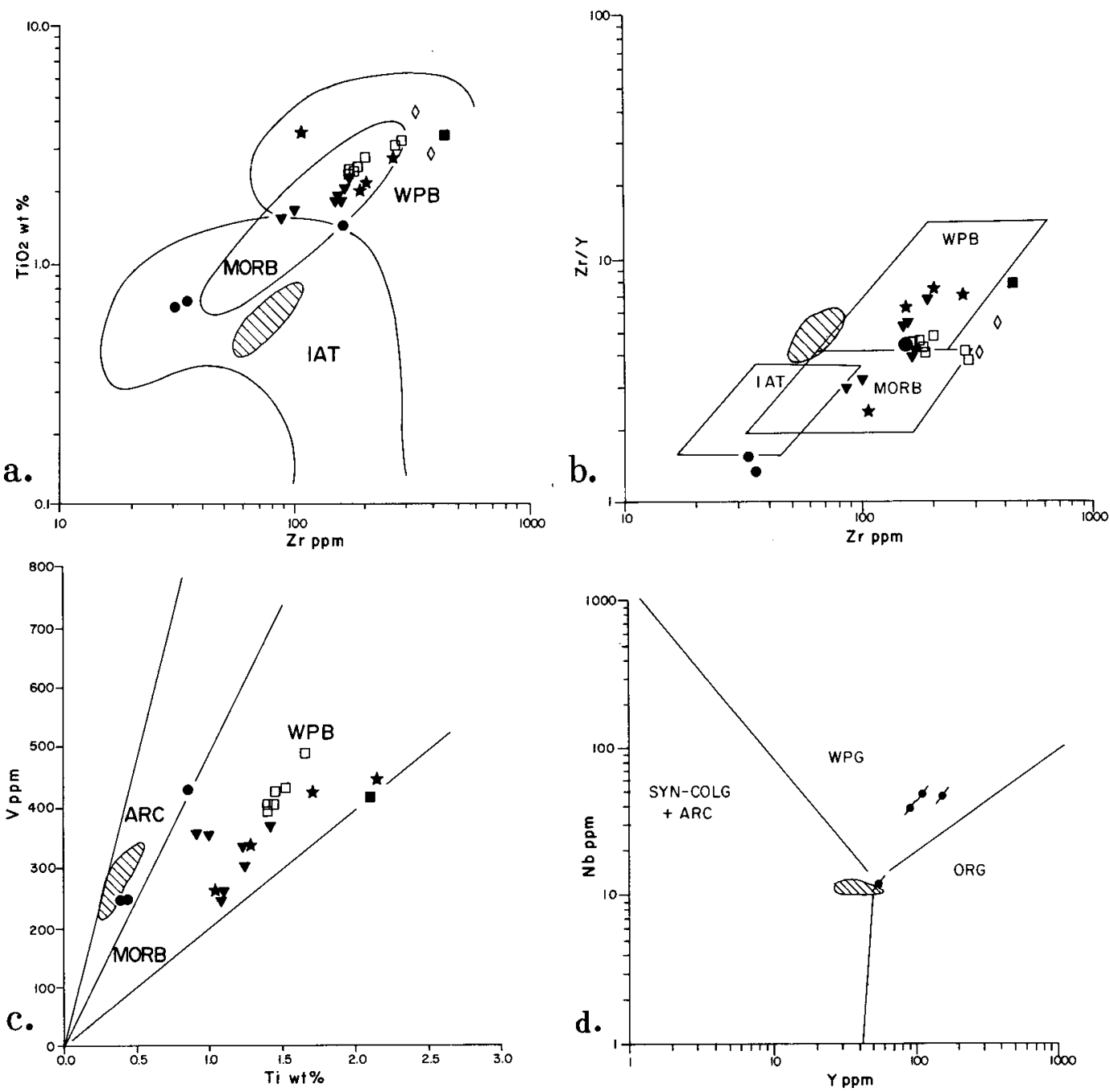

Fig. 4. Diagrams illustrating tectonic setting of the mafic and felsic volcanic rocks in the Annidale Group and contemporary volcanic suites in the region. Symbols as on Figure 3. Diagonal ruled area includes samples from the Woodstock-Meductic arc (after Dostal, 1989). (a) $\mathrm{Zr}_{\mathrm{r}} \mathrm{TiO} 2$ discriminant diagram (fields after Pearce, 1975). (b) Zr/Y-Zr discriminant diagram (fields after Pearce and Norry, 1979). (c) Ti-V discriminant diagram (fields after Shervais, 1982). (d) Nb-Y discriminant diagram for granites applied to felsic volcanic rocks from the Annidale Group (fields after Pearce et al., 1984). MORB = mid-oceanic ridge basalt, WPB = within-plate basalt, $\mathrm{IAT}=$ island arc tholeiite, $\mathrm{SYN}-\mathrm{COLG}=$ syn-collision granite, VAG = volcanic arc granite, $\mathrm{WPG}=$ within-plate granite, $\mathrm{ORG}=$ oceanic ridge granite.
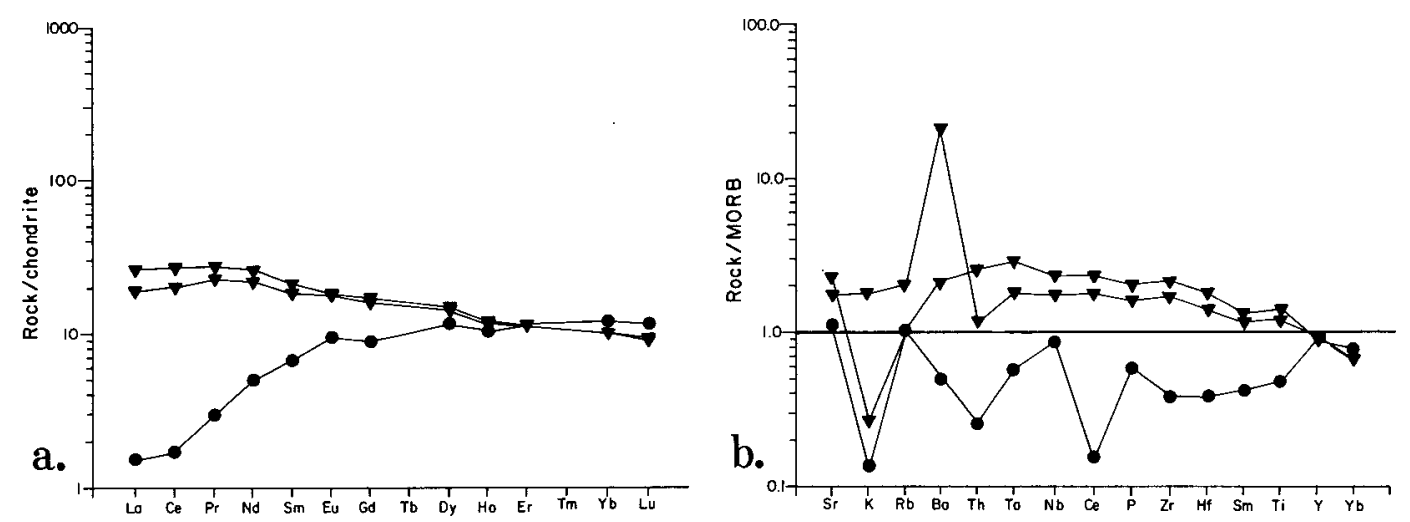

Fig. 5. Rare earth element and multielement profiles of selected samples from the Annidale Group. Symbols as on Figure 3. (a) Chondritenormalized rare earth profile (normalization values from Nakamura, 1974). (b) MORB-normalized (Pearce, 1982) multielement diagrams for Annidale Group. 
tion envisaged is similar in some respects to that in central Newfoundland where complexes of mafic and ultramafic rocks exhibit chemical characteristics indicating complex magmatic histories. These complexes define major zonal and subzonal boundaries between the Gander and Dunnage zones, and, along with other associated sequences of volcanic and sedimentary rocks, represent vestiges of Iapetus Ocean (O'Neill, 1991; Jenner and Swinden, 1993). The rocks of the fuchsite zone and the Dick Mine area may define a similar boundary, but in this case, between the surface expression of the Avalon Zone and the Gander Zone. The Annidale Subzone probably represents a remnant of the Iapetus Ocean.

\section{ACKNOWLedGements}

The authors express thanks to Les Fyffe, Cees van Staal, Sue Johnson and Glen Lutes for numerous thoughtful discussions on the geology of the Annidale area. The manuscript benefited greatly from reviews by Ken Currie, Scott Swinden, Sandra Barr and an unknown reviewer. The manuscript was typed by Lois Lafferty and diagrams drafted by Maurice Mazzerolle. Funding for this project was provided by the New Brunswick Department of Natural Resources, the Geological Survey of Canada and NATO. Analytical and technical assistance was provided at Keele University by Margaret Aikin and David Emley.

Barker, F., Sutherland Brown, A., Budahn, J.R., and Plafker, G. 1989. Back-arc with frontal-arc component origin of Triassic Karmutsen Basalt, British Columbia, Canada. Chemical Geology, 75, pp. 81102.

Dostal, J. 1989. Geochemistry of Ordovician volcanic rocks of the Tetagouche Group of southwestern New Brunswick. Atlantic Geology, 25, pp. 199-209.

FYFFE, L.R. and RivA, J. 1990. Revised stratigraphy of the Cookson Group of southwestern New Brunswick and adjacent Maine. Atlantic Geology, 26, pp. 271-276.

Fyffe, L.R., Stewart, D.B., and Ludman, A. 1988. Tectonic significance of black pelites and basalts in the St. Croix Terrane, coastal Maine and New Brunswick. Maritime Sediments and Atlantic Geology, 24, pp. 281-288.

Fyffe, L.R., Van StaAl, C.R., and Winchester, J.A. 1990. Late Precambrian-Early Paleozoic volcanic regimes and associated massive sulphide deposits in the northeastern mainland Appalachians. Canadian Institute of Mining and Metallurgy, Bulletin 83, No. 938, pp. 70-78.

GrahaM, C.M. 1976. Petrochemistry and tectonic significance of Dalradian metabasaltic rocks of the SW Scottish Highlands. Journal of the Geological Society, London, 132, pp. 61-84.

Jenner, G.A. and Swinden, H.S. 1993. The Pipestone Pond Complex, central Newfoundland: complex magmatism in an eastern Dunnage Zone ophiolite. Canadian Journal of Earth Sciences, 30, pp. $434-448$.

Ludman, A. 1987. Pre-Silurian stratigraphy and tectonic significance of the St. Croix Belt, southeastern Maine. Canadian Journal of Earth Sciences, 24, pp. 2459-2469.

MCCutcheon, S.R. and Ruttenberg, A.A. 1987. Geology and mineral deposits of the Annidale - Nerepis area. New Brunswick Department of Natural Resources and Energy, Mineral Resources Division, Memoir 2, $141 \mathrm{p}$.

McLeod, M.J., Rumenberg, A.A., and Krogh, T.E. 1991a. A previously unrecognized Lower Ordovician sequence in southern New Brunswick: evidence for multistage development of Iapetus? (ab- stract). Atlantic Geoscience Society Colloquium, Amherst, Nova Scotia. Atlantic Geology, 2, p. 157.

McLeod, M.J., Rutengerg, A.A., and Johnson, S.C. 1991b. Compilation and correlation of southwestern New Brunswick geology, Queens, Kings, Saint John and Sunbury Counties. In Project Summaries for 1991, Sixteenth Annual Review of Activities. Edited by S.A. Abbott. New Brunswick Department of Natural Resources and Energy, Mineral Resources Division, Information Circular 91-2, pp. 128-133.

McLeod, M.J., Rutenberg, A.A., and Krogh, T.E. 1992. Geology and $\mathrm{U}-\mathrm{Pb}$ geochronology of the Annidale Group, southern New Brunswick: Lower Ordovician marine magmatism near the southeast margin of Iapetus. Atlantic Geology, 28, pp. 181-192.

MiYASHIRO, A. 1974. Volcanic rock series in island arcs and active continental margins. American Journal of Sciences, 274, pp. 321355.

Nakamura, Y. 1974. Determination of REE, Ba, Fe, Mg, $\mathrm{Na}$ and $\mathrm{K}$ in carbonaceous and ordinary chondrites. Geochimica et Cosmochimica Acta, 38, pp. 757-775.

O'NeILL, P.P. 1991. Geology of the Weir's Pond area, Newfoundland (NTS 21E/1). Newfoundland Department of Mines and Energy, Geological Survey Branch, Report 91-3, 144 p.

Pearce, J.A. 1975. Basalt geochemistry used to investigate post-tectonic environments on Cyprus. Tectonophysics, 25, pp. 41-67. 1982. Trace element characteristics of lavas from destructive plate boundaries. In Andesites: Orogenic andesites and related rocks. Edited by R.S. Thorpe. John Wiley and Sons, New York, pp. 525-548.

Pearce, J.A. and Norry, M.J. 1979. Petrogenetic implications of $\mathrm{Ti}$, $\mathrm{Zr}, \mathrm{Y}$ and $\mathrm{Nb}$ variations in volcanic rocks. Contributions to Mineralogy and Petrology, 69, pp. 33-47.

Pearce, J.A., Harris, B.W., and Tindle, A.G. 1984. Trace element discrimination diagrams for the tectonic interpretation of granitic rocks. Journal of Petrology, 25, pp. 956-983.

Shervass, J.W. 1982. Ti-V plots and the petrogenesis of modern and ophiolitic lavas. Earth and Planetary Science Letters, 57, pp. 101118.

Stillman, C.J. and Williams, C.T. 1979. Geochemistry and tectonic setting of some Ordovician rocks in east and southeast Ireland. Earth and Planetary Science Letters, 41, pp. 288-310.

VAN StaAl, C.R. and FyfFe, L.R. 1991. Dunnage and Gander Zones, New Brunswick: Canadian Appalachians region. New Brunswick Department of Natural Resources and Energy, Mineral Resources Division, Geoscience Report 91-2, 39 p.

Van StaAl, C.R., Winchester, J.A., and Bedard, J.H. 1991. Geochemical variations in Middle Ordovician volcanic rocks of the northern Miramichi Highlands and their tectonic significance. Canadian Journal of Earth Sciences, 28, pp. 1031-1049.

Williams, H. 1979. Appalachian orogen in Canada. Canadian Journal of Earth Sciences, 16, pp. 792-807.

WiNCHESTER, J.A. and FLOYD, P.A. 1977. Geochemical discrimination of different magma series and their differentiation products using immobile elements. Chemical Geology, 20, pp. 325-343.

Winchester, J.A., Van Staal, C.R., and Langton, J.P. 1992. The Ordovician volcanics of the Elmtree - Belledune inlier and their relationship to volcanics of the northern Miramichi Highlands, New Brunswick. Canadian Journal of Earth Sciences, 29, pp. 1430-1447.

WooD, D.A. 1978. Major and trace element variations in the Tertiary lavas of eastern Iceland and their significance with respect to the Iceland Geochemical Anomaly. Journal of Petrology, 19, pp. 393436. 